\title{
Phenology of German Chamomile and its Changes under Different Irrigation Regimes and Plant Densities
}

\author{
Alireza PIRZAD ${ }^{1)}$, Mohammad Reza SHAKIBA ${ }^{2)}$, Saeed ZEHTAB-SALMASI'2), Seyed \\ Abolghasem MOHAMMADI'), Reza DARVISHZADEH ${ }^{1)}$, Abbas HASSANI ${ }^{3)}$ \\ 1) Urmia University, Faculty of Agriculture, Department of Agronomy and Plant Breeding, \\ Urmia,Iran;a.pirzad@urmia.ac.ir,r.darvishzadeh@urmia.ac.ir \\ 2) Tabriz University, Faculty of Agriculture, Department of Agronomy and Plant Breeding, Tabriz, \\ Iran;shakibamr438@yahoo.com,szehtabi@yahoo.com,sa_mohammadi@yahoo.com \\ 3) Urmia University, Institute of Biotechnology, Department of Medicinal and Industrial Plants, Urmia, Iran; horthasani@yahoo.com
}

\begin{abstract}
In order to definite growth stages of Matricaria chamomilla L., 40 plants were planted with $200 \times 200 \mathrm{~cm}$ distance from each other. To determine the phenology under different water stress condition and plant densities, an experiment was conducted in factorial based on randomized complete block design with two factors including irrigation at 4 levels $(25,50,75$, and 100 mm evaporation from pan class A), and plant density at 5 levels (cultivation in $30 \mathrm{~cm}$ rows with 5, 10, 15, 20 and $25 \mathrm{~cm}$ intra-row spaces) with three replications. Definition of growth stages including the maximum number of nodes, sub stems and tillers were 21, 20 and 14 that were occurred at 970, 1088 and $1088^{\circ} \mathrm{C}$ growth degree-days, respectively. The numbers of nodes were 28.6, 30.0, 30.2 and 27.8, of sub stem were 19.2, 18.4, 19.8 and 18.4; and of tillers were 14.8, 14.0, 15.0 and 14.4 that were obtained from irrigation at 25, 50, 75, and 100 mm evaporation from pan, respectively. In the other hand, the number of nodes as follow 28.25, 29.00, 29.75, 29.75 and 29.00; sub stem as 17.50, 20.00, 20.75, 19.00 and 17.50; and tillers were 15.00, 13.50, 14.75, 14.00 and 15.50 that were obtained from 5, 10, 15, 20 and $25 \mathrm{~cm}$ intra-row spacing, respectively. Differences by irrigation on GDDs values were observed at the second harvest. However the earliest observation of flower and seed receiving at the first harvest occurred on $5 \mathrm{~cm}$ intra-row spacing. These changes were identical by GDDs for second harvest of flower, but with mild slope of reduction. There were no differences in number of leaves and tillers among irrigation levels and plant densities.
\end{abstract}

Keywords: intra-row spacing, growth degree-days, growth stage, Matricaria chamomilla, water stress

\section{Introduction}

Prior to any serious consideration of the chemical composition of chamomile, the botanical and taxonomical identity needs to be understand (Mann and Staba, 1992). Chamomile (Matricaria chamomilla L.), family Asteraceae, there so called German, Hungarian or small chamomilla is a native of Europe and is cultivated extensively in Hungary, Germany, Russia and Yugoslavia. In India M. chamomilla (Persian chamomilla, locally called 'Baboonaj') has been reported to grow in the plains. Matricaria has a wide domestic use, especially among the Germans (Singh, 1982). Chamomile is an annual with an erect or spreading height and usually attains a height of 50 to $65 \mathrm{~cm}$ and in some cases about $85 \mathrm{~cm}$. The stem is glabrous, branched; leaves very green and smooth, 2-3 perinatiseet with segments short and very linear, giving the leaf finely dissected appearance. Head solitary, long peduncled, with white ray and yellow disc florets. Receptacle conic, elongated during fruiting (Singh, 1982; Salamon, 1992). The world market currently has German chamomile drug of various origin and therapeutically values. In the 1970 s, plant material was evaluated by the content of essential oil and the content of chamazulene (Salamon, 1998).

The changes in the soil moisture regime can alter the root morphology and anatomy, the pore size distribution, and the angle of roots penetration, which affect root proliferation. The major types of stresses which potentially affect plant growth on a global basis are water (flooding and drought) stress (Pessarakli, 1999). In waterlogged soils, slowing down of shoot and root growth was more closely related to the declining $\mathrm{O}_{2}$ concentration in the soil solution than to the concentration of dissolved inorganic nitrogen (Trought and Drew, 1980). Flooding is the saturation of the soil root zone with water. Flooding (water logging) occurs when inundation persists as a result of inadequate surface and/or subsurface drainage and the aeration status of the soil system decreases below critical 
44

limits. Water stress (drought) is also an important limitation to crop production. Reduction in photosynthetic activity and increases in leaf senescence are symptomatic of water stress and adversely affect crop growth. Water stress also reduces the net $\mathrm{CO}_{2}$ assimilation (Pessarakli, 1999).

Plant density is invariably linked with yield, the more plant stands there are up to a certain limit, the higher the expected yield (Bertoia et al., 1998). The dominant production practice is for farmers to plant crops (cereals) at spacing in the range of $30-35 \mathrm{~cm}$, which on average gives about 44.000 to 38.000 plants per hectare. In addition, in most irrigation schemes, water is not a limiting factor, what tends to happen is rather over-irrigation because of the abundance of water. Research has also shown that farmers apply on average twice the moisture consumptive use requirements of crops on each irrigation level. This is deleterious to crops and retards proper growth and subsequent yield. Farmers thus face the problem of knowing the correct plant density to sow and also the exact amount (or optimum amount) of water to apply, which amount to apply in areas of abundance and areas of scarcity (Sani $e t$ al., 2008).

\section{Materials and methods}

This research was conducted between May and August for two seasons (2003 and 2004) at the field of Dept. Agronomy and Plant Breeding of Faculty of Agriculture of Urmia University (latitude $37.53^{\circ} \mathrm{N}, 45.08^{\circ} \mathrm{E}, 1320$ $\mathrm{m}$ above sea level) Urmia, Iran. Mean of air temperature (15.6, 16.6, 23.4, 23.4 $\left.4^{\circ} \mathrm{C}\right)$, evaporation (191.1, 200.2, 272.0, $296.9 \mathrm{~mm})$, rainfall $(9,5.9,0,0 \mathrm{~mm})$ and relative humidity $(55.7,52.2,51.7,51.3 \%)$ for May, June, July and August 2003, respectively. However, mean of air temperature $\left(14.8,19.9,22.1,23.2^{\circ} \mathrm{C}\right)$, evaporation $(165.1,230.1$, $227.3,271.8 \mathrm{~mm})$, rainfall $(60,3.3,16.3,0 \mathrm{~mm})$ and relative humidity $(62.7,52.1,56.8,49.9 \%)$ for May, June, July and August 2004, respectively. The soil texture of experiment site was clay-loam ( $28 \%$ silt, $33 \%$ clay, $40 \%$ sand) with $22.5 \%$ field capacity, $1.54 \mathrm{~g} \mathrm{~cm}^{-3}$ soil density, $1.98 \%$ organic mater, $\mathrm{pH}=7.6$.

This communication, based on a 2-year (2003 and 2004) field study, describes the drought susceptibility of 5 plant density of German chamomile, expressed in terms of plant phenology. The seeds of Matricaria chamomilla $\mathrm{L}$. c.v. 'Bodegold', a tetraploide variety were planted on 1 May both two year. Experiments carried out in factorial based on Randomized Complete Block Design with two factors, Irrigation and plant density. Irrigation regimes $\left(\mathrm{I}_{1}, \mathrm{I}_{2}, \mathrm{I}_{3}\right.$ and $\left.I_{4}\right)$ irrigation at $25,50,75$ and $100 \mathrm{~mm}$ evaporation from class A pan, respectively) and plant density $\left(\mathrm{D}_{1}, \mathrm{D}_{2}, \mathrm{D}_{3}, \mathrm{D}_{4}\right.$ and $\mathrm{D}_{5}$ cultivation in $30 \mathrm{~cm}$ rows with $5,10,15,20$ and $25 \mathrm{~cm}$ intra-row spaces, respectively) treatments have done at rosette stage. Plant growth was continuously monitored during the whole experimental period by mechanical control of weeds. However, to determine a complete phenol- ogy of German chamomile, 40 plants were planted with $200 \mathrm{~cm}$ distance from each other in 2003 and 2004.

Statistical evaluation was performed using MSTATC software (Michigan State University, 1988). The effects of Irrigation regimes (I) and Plant density (D) as well as the interactions of these two factors were analyzed with the analysis of variance. The results of statistical analysis are expressed by F-values; asterisks indicate $\mathrm{p}$-values: $\mathrm{p}^{*}<0.05$ and $\mathrm{p}^{* *}<0.01$. The comparison of means carried out with SNK (Student-Neuman Keul's test).

\section{Results and discussion}

Definition of growth stages of Matricaria chamomilla L. at the experiment site in 2003 and 2004, showed in Tab. 2. In this study, the maximum number of nodes $\left(V_{n}\right)$, sub stems $\left(\mathrm{S}_{\mathrm{n}}\right)$ and tillers $\left(\mathrm{T}_{\mathrm{n}}\right)$ were 21,20 and 14 at the GDDs of 970,1088 and $1088^{\circ} \mathrm{C}$, respectively (Tab. 1).

Means of vegetative and generative growth stages of German chamomile under irrigation regimes and plant distances on constant rows (plant density) showed on Tab. 2 and 3. Vegetative stages: $V_{e}, V_{c}, V_{1}, V_{2}$ and $V_{3}$ were same in all treatments, after that and carrying out of irrigation and plant density treatments differences were showed. The numbers of node were 28.6, 30.0, 30.2 and 27.8 at the irrigation at 25, 50,75 and $100 \mathrm{~mm}$ evaporation from class A pan, respectively. It seems excess water on $\mathrm{I}_{1}$ and water deficit on $\mathrm{I}_{4}$ lead to reduce number of nodes. Means of the number of sub stem were 19.2, 18.4, 19.8 and 18.4; and the number of tillers were $14.8,14.0,15.0$ and $14.4 \mathrm{ob}$ tained from $\mathrm{I}_{1}, \mathrm{I}_{2}, \mathrm{I}_{3}$ and $\mathrm{I}_{4}$, respectively. $\mathrm{R}_{1}$ stage was 73 days after planting at $\mathrm{I}_{1}$ and $\mathrm{I}_{2}$, but 66 days after planting at $\mathrm{I}_{3}$ and $\mathrm{I}_{4}$. However, $\mathrm{R}_{2}$ stage was 87 days after planting in $\mathrm{I}_{1}^{3}$ and $\mathrm{I}_{2}^{4}$ and 80days after planting in $\mathrm{I}_{3}$ and $\mathrm{I}_{4} \cdot \mathrm{R}_{3 \mathrm{a}}$ were occurred 87 days after planting in all irrigation regimes, but $\mathrm{R}_{3} \mathrm{~b}$ were 113 days after planting for $\mathrm{I}_{3}$ and $\mathrm{I}_{4}$ and 111 days after planting for $\mathrm{I}_{1}$ and $\mathrm{I}_{2} . \mathrm{R}_{4 \mathrm{a}}$ were occurred 105 days after planting in all irrigation regimes, but $\mathrm{R}_{4 \mathrm{~b}}$ were 122 days after planting for $\mathrm{I}_{1}, \mathrm{I}_{2}$ and $\mathrm{I}_{3}$ that were 7 days later than $\mathrm{I}_{4}$. These results, any differences at the first harvest and differences at the second harvest, are due to ending a growth stage at the second stage while at the first one we cut the growth and harvest its flowers and seeds. Rs, flowering of sub stems occurred 80 days after planting at the $\mathrm{I}_{4}$, while it occurred 87 days after planting at the $\mathrm{I}_{1}, \mathrm{I}_{2}$ and $\mathrm{I}_{3}$ (Tab. 2). It seems the strength stresses led to early observation on generative stages.

The number of nodes $28.25,29.00,29.75,29.75$ and 29.00; sub stem 17.50, 20.00, 20.75, 19.00 and 17.50; and tillers were $15.00,13.50,14.75,14.00$ and 15.50 obtained from $\mathrm{D}_{1}, \mathrm{D}_{2}, \mathrm{D}_{3}, \mathrm{D}_{4}$ and $\mathrm{D}_{5}$, respectively. Initial of generative stage, $R_{1}$ was occurred 66 days after planting at the $\mathrm{D}_{1}$ and $\mathrm{D}_{5}$ that were 7 days earlier than $\mathrm{D}_{2}, \mathrm{D}_{3}$ and $\mathrm{D}_{4}$. However occurrence of $R_{2}$ was 73 days after planting at the $D_{1}$ and $\mathrm{D}_{5}$ like $\mathrm{R}_{1}$ in comparison with $\mathrm{D}_{2}, \mathrm{D}_{3}$ and $\mathrm{D}_{4} . \mathrm{R}_{3 \mathrm{a}}$ were occurred 84, 86, 87, 88 and 89 days after planting and $\mathrm{R}_{4 a}$ 
Tab. 1. Definition of growth stages of Matricaria chamomilla L. at the experiment site in 2003 and 2004

\begin{tabular}{|c|c|c|c|}
\hline $\begin{array}{l}\text { Growth } \\
\text { Stage }\end{array}$ & Symbol & Definition & $\begin{array}{l}\text { GDDs } \\
\text { (mean } \\
2 \text { year) }\end{array}$ \\
\hline \multirow{43}{*}{ 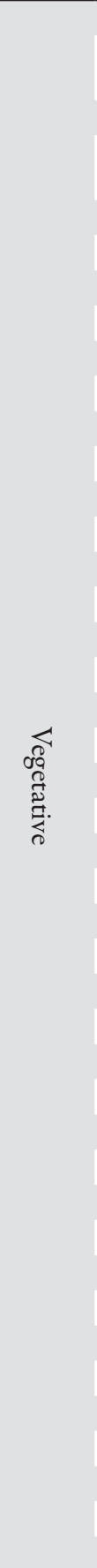 } & $\mathrm{V}_{\mathrm{c}}$ & Emerging (Cotyledons are top of the Soil) & 195 \\
\hline & $\mathrm{V}_{\mathrm{c}}$ & $\begin{array}{l}\text { Appearance of Cotyledons leaves } \\
\text { (simple leaf fully opened) }\end{array}$ & 219 \\
\hline & $\mathrm{V}_{1}$ & Appearance of First node on stem (2 leaves) & 274 \\
\hline & $\mathrm{V}_{2}$ & $\begin{array}{l}\text { Appearance of Second node } \\
\text { on stem ( } 2 \text { leaves) }\end{array}$ & 364 \\
\hline & $\mathrm{V}_{3}$ & Appearance of third node on stem ( $5^{\text {th }}$ leaf $)$ & 407 \\
\hline & $\mathrm{V}_{4}$ & Appearance of $4^{\text {th }}$ node on stem ( $6^{\text {th }}$ leaf $)$ & 437 \\
\hline & $\mathrm{V}_{5}$ & Appearance of $5^{\text {th }}$ node on stem ( $7^{\text {th }}$ leaf $)$ & 484 \\
\hline & $\mathrm{V}_{6}$ & Appearance of $6^{\text {th }}$ node on stem ( $8^{\text {th }}$ leaf $)$ & 531 \\
\hline & $\mathrm{V}_{7}$ & Appearance of $7^{\text {th }}$ node on stem ( $9^{\text {th }}$ leaf) & 580 \\
\hline & $\mathrm{V}_{8}$ & Appearance of $8^{\text {th }}$ node on stem ( $10^{\text {th }}$ leaf $)$ & 600 \\
\hline & $\mathrm{V}_{9}$ & Appearance of $9^{\text {th }}$ node on stem ( $11^{\text {th }}$ leaf $)$ & 620 \\
\hline & $\mathrm{V}_{10}$ & Appearance of $10^{\text {th }}$ node on stem ( $12^{\text {th }}$ leaf $)$ & 641 \\
\hline & $\mathrm{V}_{11}$ & Appearance of $11^{\text {th }}$ node on stem ( $13^{\text {th }}$ leaf $)$ & 662 \\
\hline & $\mathrm{V}_{12}$ & Appearance of $12^{\text {th }}$ node on stem (1 $14^{\text {th }}$ leaf $)$ & 681 \\
\hline & $\mathrm{V}_{\mathrm{n}}$ & Appearance of $\mathrm{N}^{\text {th }}$ node on stem ( $\mathrm{N}-2^{\text {th }}$ leaf $)$ & $\mathrm{N}$ \\
\hline & $S_{1}$ & Appearance of First Sub stem & 650 \\
\hline & $\mathrm{S}_{2}$ & Appearance of Second Sub stem & 680 \\
\hline & $\mathrm{S}_{3}$ & Appearance of Third Sub stem & 710 \\
\hline & $\mathrm{S}_{4}$ & Appearance of Forth Sub stem & 748 \\
\hline & $\mathrm{S}_{5}$ & Appearance of $5^{\text {th }}$ Sub stem & 788 \\
\hline & $\mathrm{S}_{6}$ & Appearance of $6^{\text {th }}$ Sub stem & 910 \\
\hline & $\mathrm{S}_{7}$ & Appearance of $7^{\text {th }}$ Sub stem & 970 \\
\hline & $\mathrm{S}_{8}$ & Appearance of $8^{\text {th }}$ Sub stem & 990 \\
\hline & $\mathrm{S}_{9}$ & Appearance of $9^{\text {th }}$ Sub stem & 1000 \\
\hline & $S_{10}$ & Appearance of $10^{\text {th }}$ Sub stem & 1015 \\
\hline & $S_{11}$ & Appearance of $11^{\text {th }}$ Sub stem & 1023 \\
\hline & $S_{12}$ & Appearance of $12^{\text {th }}$ Sub stem & 1032 \\
\hline & $S_{n}$ & Appearance of $\mathrm{N}^{\text {th }}$ Sub stem & $\mathrm{N}$ \\
\hline & $\mathrm{T}_{1}$ & Appearance of First Tiller & 680 \\
\hline & $\mathrm{T}_{2}$ & Appearance of Second Tiller & 690 \\
\hline & $\mathrm{T}_{3}$ & Appearance of Third Tiller & 707 \\
\hline & $\mathrm{T}_{4}$ & Appearance of Forth Tiller & 725 \\
\hline & $\mathrm{T}_{5}$ & Appearance of $5^{\text {th }}$ Tiller & 743 \\
\hline & $\mathrm{T}_{6}$ & Appearance of $6^{\text {th }}$ Tiller & 760 \\
\hline & $\mathrm{T}_{7}$ & Appearance of $7^{\text {th }}$ Tiller & 788 \\
\hline & $\mathrm{T}_{8}$ & Appearance of $8^{\text {th }}$ Tiller & 838 \\
\hline & $\mathrm{T}_{9}$ & Appearance of $9^{\text {th }}$ Tiller & 938 \\
\hline & $\mathrm{T}_{10}$ & Appearance of $10^{\text {th }}$ Tiller & 970 \\
\hline & $\mathrm{T}_{11}$ & Appearance of $11^{\text {th }}$ Tiller & 1010 \\
\hline & $\mathrm{T}_{12}$ & Appearance of $12^{\text {th }}$ Tiller & 1088 \\
\hline & $T_{n}$ & Appearance of $\mathrm{N}^{\text {th }}$ Tiller & $\mathrm{N}$ \\
\hline & TT & Appearance of Sub Tiller & 1043 \\
\hline & SS & Appearance of Sub Stem from Sn & 1184 \\
\hline
\end{tabular}

were occurred 102, 103, 104, 105 and 108 days after planting in $\mathrm{D}_{1}, \mathrm{D}_{2}, \mathrm{D}_{3}, \mathrm{D}_{4}$ and $\mathrm{D}_{5}$, respectively. But $\mathrm{R}_{3 \mathrm{~b}}$ were 113 days for $\mathrm{D}_{1}$ and $\mathrm{D}_{2}, 114$ days for $\mathrm{D}_{3}$ and $\mathrm{D}_{4}$, and 115 days for $\mathrm{D}_{5}$, while $\mathrm{R}_{4 \mathrm{~b}}$ for $\mathrm{D}_{1}, \mathrm{D}_{2}$ and $\mathrm{D}_{3}$ were 119 days and for $\mathrm{D}_{4}$ and $\mathrm{D}_{5}$ were 120 days after planting. Rs Stage was 87 days for $\mathrm{D}_{1}, \mathrm{D}_{3}, \mathrm{D}_{4}$ and $\mathrm{D}_{5}$, and 94 days after planting for $\mathrm{D}_{2}$ (Tab. 3). Accumulative Growth Degree Days for German
Tab. 1. Definition of Growth stages of Matricaria chamomilla L. at the experiment site in 2003 and 2004 (Continue)

\begin{tabular}{|c|c|c|c|}
\hline $\begin{array}{l}\text { Growth } \\
\text { Stage }\end{array}$ & Symbol & Definition & $\begin{array}{l}\text { GDDs } \\
\text { (mean } \\
2 \text { year) }\end{array}$ \\
\hline \multirow{6}{*}{ 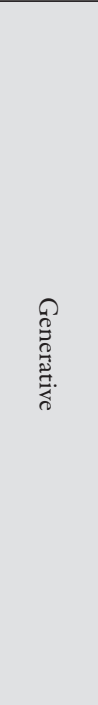 } & $\mathrm{R}_{1}$ & Flowering initialize & 970 \\
\hline & $\mathrm{R}_{2}$ & $\begin{array}{l}\text { Flowers are fully opened, ligulae petals } \\
\text { horizontal, Smooth Receptacle, yellowish } \\
\text { florets with pollen grain on it }\end{array}$ & 1029 \\
\hline & $\mathrm{R}_{\mathrm{S}}$ & Flowering initialize on Sub stem & 1026 \\
\hline & $\mathrm{R}_{3}$ & $\begin{array}{l}\text { Receptacle is conic and swollen (cone-shape } \\
\text { capitulum, hollow bottom), ligulae petals } \\
\text { are swept and their color changed and } \\
\text { grain is formed but soft, flowers in optimal } \\
\text { condition for essential bearing. In harvested } \\
\text { condition there are } 2 \text { harvests as: } \mathrm{R}_{3 \mathrm{a}} \text { first } \\
\text { harvest and } \mathrm{R}_{3 \mathrm{~b}} \text { the second harvest. }\end{array}$ & $\begin{array}{c}1120- \\
1680\end{array}$ \\
\hline & $\mathrm{R}_{4}$ & $\begin{array}{l}\text { Ligulae petals are vertical and up down, } \\
\text { florets completely ripened except of mid } \\
\text { florets, grains darken and hard. In harvested } \\
\text { condition there are } 2 \text { harvests as: } \mathrm{R}_{4 \mathrm{a}} \text { first } \\
\text { harvest and } \mathrm{R}_{4 \mathrm{~b}} \text { the second harvest. }\end{array}$ & $\begin{array}{c}1338- \\
1705\end{array}$ \\
\hline & $\mathrm{D}$ & $\begin{array}{l}\text { Plant drying initialize, defoliate 2-3 downiest } \\
\text { leaves, a few numbers of small flowers } \\
\text { appears at the end of stem and substem. }\end{array}$ & 1305 \\
\hline
\end{tabular}

chamomile during growth season of experiment site was shown on Fig. 1. Results of ANOVA showed that GDDs for first harvests of flower and seed were not affected by irrigation regimes, but plant density had significant effect on them $(P<0.01)$. Significant interaction between year and plant density showed different procedure of GDDs for first harvest of flower and seed (Tab. 4). Despite of these significances, GDDs for first harvest of flower and seed have same trends, increasing with reducing plant density in both 2 years (Fig. 2). We found the maximum amounts of GDDs at the first harvest of flower (1075) and seed (1409) belonged to D5 in which declined with reducing intra-row distances and received the minimum amounts for flower (1011) and seed (1300) harvest in D1 (Fig. 3). At the second harvest, GDDs for harvest of flower affected by irrigation regime and plant density $(\mathrm{P}<0.01)$, But the effect of plant density was non-significant for seed harvest (Tab. 4). Maximum amounts of GDDs at the second harvest of flower belonged to $\mathrm{I}_{1}$ and $\mathrm{I}_{2}$ and the minimum amount obtained from $\mathrm{I}_{3}$ and $\mathrm{I}_{4}$. These values obtained at $\mathrm{I}_{3}$ and $\mathrm{I}_{4}$ for maximum and minimum, respectively. Comparisons of means showed the same procedures on GDDs like one of the first harvest of flowers affected by different plant density (Fig. 2). Overall differences by irrigation on GDDs values observed at the second harvest. Water stress at the strength level led to earlier occurrence of receiving both flower and seed. However the earliest observation of flower and seed receiving at the first harvest occurred on the highest density of plant. It seems that increasing the distances between plants provide a condition to branching and great vegetative growth. These changes were the same with GDDs for second harvest of flower, but with mild 
Tab. 2. Growth stages of Matricaria chamomilla L. under irrigation regimes

\begin{tabular}{|c|c|c|c|c|c|c|}
\hline \multirow{2}{*}{$\begin{array}{c}\text { Days } \\
\text { after } \\
\text { Planting }\end{array}$} & \multicolumn{2}{|c|}{ GDDs } & \multicolumn{4}{|c|}{ Irrigation regimes (irrigation after evaporation from class A pan) } \\
\hline & 2003 & 2004 & $\mathrm{I}_{1}(25 \mathrm{~mm})$ & $\mathrm{I}_{2}(50 \mathrm{~mm})$ & $\mathrm{I}_{3}(75 \mathrm{~mm})$ & $\mathrm{I}_{4}(100 \mathrm{~mm})$ \\
\hline 0 & 0 & 0 & Planting & Planting & Planting & Planting \\
\hline 26 & 227 & 205 & $\mathrm{~V}_{\mathrm{c}}$ & $\mathrm{V}_{\mathrm{c}}$ & $\mathrm{V}_{\mathrm{c}}$ & $\mathrm{V}_{\mathrm{c}}$ \\
\hline 28 & 247 & 229 & $\mathrm{~V}_{c}$ & $\mathrm{~V}_{c}$ & $V_{c}$ & $\mathrm{~V}_{c}$ \\
\hline 33 & 290 & 280 & $\mathrm{~V}_{1}$ & $\mathrm{~V}_{1}$ & $\mathrm{~V}_{1}$ & $\mathrm{~V}_{1}$ \\
\hline 42 & 354 & 388 & $\mathrm{~V}_{2}$ & $\mathrm{~V}_{2}$ & $\mathrm{~V}_{2}$ & $\mathrm{~V}_{2}$ \\
\hline 45 & 383 & 423 & $\mathrm{~V}_{3}$ & $\mathrm{~V}_{3}$ & $\mathrm{~V}_{3}$ & $\mathrm{~V}_{3}$ \\
\hline 52 & 454 & 522 & $\mathrm{~V}_{5.4}$ & $\mathrm{~V}_{7}$ & $\mathrm{~V}_{7.4}$ & $\mathrm{~V}_{9,4}$ \\
\hline 59 & 552 & 636 & $\mathrm{~V}_{7.2}$ & $\mathrm{~V}_{10.2}$ & $\mathrm{~V}_{10.2}$ & $\mathrm{~V}_{14.2}$ \\
\hline 66 & 664 & 729 & $\mathrm{~V}_{8.8} \mathrm{~S}_{3.4} \mathrm{~T}_{4.6}$ & $\mathrm{~V}_{12} \mathrm{~S}_{2.6} \mathrm{~T}_{5.4}$ & $\mathrm{R}_{1} \mathrm{~V}_{12.6} \mathrm{~S}_{5.2} \mathrm{~T}_{6.4}$ & $\mathrm{R}_{1} \mathrm{~V}_{18} \mathrm{~S}_{6} \mathrm{~T}_{5.8}$ \\
\hline 73 & 788 & 827 & $\mathrm{R}_{1} \mathrm{~V}_{16.2} \mathrm{~S}_{5.6} \mathrm{~T}_{8.4}$ & $\mathrm{R}_{1} \mathrm{~V}_{17.2} \mathrm{~S}_{5.2} \mathrm{~T}_{7.6}$ & $\mathrm{R}_{2} \mathrm{~V}_{18.6} \mathrm{~S}_{8.6} \mathrm{~T}_{10}$ & $\mathrm{R}_{2} \mathrm{~V}_{22.2} \mathrm{~S}_{9.6} \mathrm{~T}_{9.8}$ \\
\hline 80 & 915 & 945 & $\mathrm{R}_{2} \mathrm{~V}_{21.8} \mathrm{~S}_{8.8} \mathrm{~T}_{11.2}$ & $\mathrm{R}_{2} \mathrm{~V}_{20.6} \mathrm{~S}_{9} \mathrm{~T}_{9.2}$ & $\mathrm{~V}_{22.4} \mathrm{~S}_{13} \mathrm{~T}_{12.6}$ & $\mathrm{RsV}_{24.8} \mathrm{~S}_{14.4} \mathrm{~T}_{12}$ \\
\hline 84 & 981 & 1010 & & & & \\
\hline 86 & 1012 & 1040 & & & & \\
\hline 87 & 1029 & 1055 & $\mathrm{R}_{3 \mathrm{a}} \mathrm{RsV}_{25.4} \mathrm{~S}_{13.8} \mathrm{~T}_{13.6}$ & $\mathrm{R}_{3 \mathrm{a}} \mathrm{RsV}_{26.2} \mathrm{~S}_{13.2} \mathrm{~T}_{12}$ & $\mathrm{R}_{3 \mathrm{a}} \mathrm{RsV}_{27} \mathrm{~S}_{16.2} \mathrm{~T}_{14}$ & $\mathrm{R}_{3 \mathrm{a}} \mathrm{V}_{26.6} \mathrm{~S}_{16.2} \mathrm{~T}_{13.6}$ \\
\hline 88 & 1043 & 1073 & & & & \\
\hline 89 & 1060 & 1090 & & & & \\
\hline 94 & 1138 & 1179 & $\mathrm{~V}_{28.6} \mathrm{~S}_{19,2} \mathrm{~T}_{14.8}$ & $\mathrm{~V}_{30} \mathrm{~S}_{18.4} \mathrm{~T}_{14}$ & $\mathrm{~V}_{30.2} \mathrm{~S}_{19.8} \mathrm{~T}_{15}$ & $\mathrm{~V}_{27.8} \mathrm{~S}_{18.4} \mathrm{~T}_{14.4}$ \\
\hline 101 & 1262 & 1298 & & & & \\
\hline 102 & 1282 & 1316 & & & & \\
\hline 103 & 1304 & 1332 & & & & \\
\hline 104 & 1324 & 1348 & & & & \\
\hline 105 & 1340 & 1362 & $\mathrm{R}_{4 \mathrm{a}}$ & $\mathrm{R}_{4 \mathrm{a}}$ & $\mathrm{R}_{4 \mathrm{a}}$ & $\mathrm{R}_{4 a}$ \\
\hline 108 & 1387 & 1412 & & & & \\
\hline 113 & 1468 & 1502 & & & $\mathrm{R}_{3 \mathrm{~b}}$ & $\mathrm{R}_{3 \mathrm{~b}}$ \\
\hline 114 & 1484 & 1516 & & & & \\
\hline 115 & 1500 & 1530 & $\mathrm{R}_{3 \mathrm{~b}}$ & $\mathrm{R}_{3 \mathrm{~b}}$ & & $\mathrm{R}_{4 \mathrm{~b}}$ \\
\hline 119 & 1562 & 1594 & & & & \\
\hline 12 & 1578 & 1610 & & & & \\
\hline 122 & 1612 & 1643 & $\mathrm{R}_{4 \mathrm{~b}}$ & $\mathrm{R}_{4 \mathrm{~b}}$ & $\mathrm{R}_{4 \mathrm{~b}}$ & \\
\hline
\end{tabular}

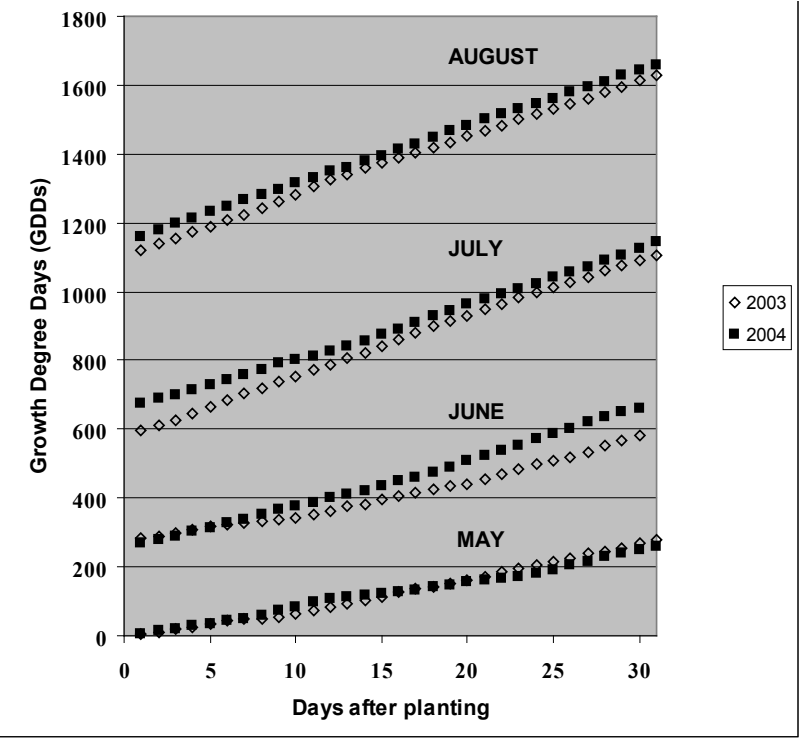

Fig. 1. Growth Degree Days (GDDs) of Matricaria chamomilla L. at the experiment site slope of reduction. At last, this slope got zero for second harvest of seed because of ending growth season on this stage.

Results showed no differences of the number of leaves and tillers among irrigation levels with means 27.377 and 12.683 , respectively. But, plant density had significant $(\mathrm{P}<0.05)$ and non-significant effect on the numbers of leaves and tillers. Despite of this significance all levels of plant densities had same numbers of leaves and tillers under among plant densities. However, there were significant interaction between irrigation and plant density on the numbers of sub stem (Tab. 4). Results indicated that levels of each factor in other factor had a same trend of the numbers of sub stem (Tab. 5).

\section{Acknowledgments} yari.

I dedicate this paper to the late Prof. Houshang Al- 
Tab. 3. Growth stages of Matricaria chamomilla L. under plant densities

\begin{tabular}{|c|c|c|c|c|c|c|c|}
\hline \multirow{2}{*}{$\begin{array}{c}\text { Days } \\
\text { after } \\
\text { Planting }\end{array}$} & \multicolumn{2}{|c|}{ GDDs } & \multicolumn{5}{|c|}{ Intra row spacing by $30 \mathrm{~cm}$ inter row spacing $(\mathrm{cm})$} \\
\hline & 2003 & 2004 & $\mathrm{D}_{1}(5 \mathrm{~cm})$ & $\mathrm{D}_{2}(10 \mathrm{~cm})$ & $\mathrm{D}_{3}(15 \mathrm{~cm})$ & $\mathrm{D}_{4}(20 \mathrm{~cm})$ & $\mathrm{D}_{5}(25 \mathrm{~cm})$ \\
\hline 0 & 0 & 0 & Planting & Planting & Planting & Planting & Planting \\
\hline 26 & 227 & 205 & $\mathrm{~V}_{\mathrm{c}}$ & $\mathrm{V}_{\mathrm{c}}$ & $\mathrm{V}_{\mathrm{c}}$ & $\mathrm{V}_{\mathrm{c}}$ & $\mathrm{V}_{\mathrm{c}}$ \\
\hline 28 & 247 & 229 & $\mathrm{~V}_{\mathrm{c}}$ & $\mathrm{V}_{\mathrm{c}}$ & $\mathrm{V}_{\mathrm{c}}$ & $\mathrm{V}_{\mathrm{c}}$ & $\mathrm{V}_{\mathrm{c}}$ \\
\hline 33 & 290 & 280 & $\mathrm{~V}_{1}$ & $\mathrm{~V}_{1}$ & $\mathrm{~V}_{1}$ & $\mathrm{~V}_{1}$ & $\mathrm{~V}_{1}$ \\
\hline 42 & 354 & 388 & $\mathrm{~V}_{2}$ & $\mathrm{~V}_{2}$ & $\mathrm{~V}_{2}$ & $\mathrm{~V}_{2}$ & $\mathrm{~V}_{2}$ \\
\hline 45 & 383 & 423 & $\mathrm{~V}_{3}$ & $\mathrm{~V}_{3}$ & $\mathrm{~V}_{3}$ & $\mathrm{~V}_{3}$ & $\mathrm{~V}_{3}$ \\
\hline 52 & 454 & 522 & $\mathrm{~V}_{8}$ & $\mathrm{~V}_{7.5}$ & $\mathrm{~V}_{6.25}$ & $\mathrm{~V}_{7.75}$ & $\mathrm{~V}_{7}$ \\
\hline 59 & 552 & 636 & $\mathrm{~V}_{11.5}$ & $\mathrm{~V}_{10.25}$ & $\mathrm{~V}_{9}$ & $\mathrm{~V}_{11.25}$ & $\mathrm{~V}_{10.25}$ \\
\hline 66 & 664 & 729 & $\mathrm{R}_{1} \mathrm{~V}_{13.75} \mathrm{~S}_{4.25} \mathrm{~T}_{5}$ & $\mathrm{~V}_{12.75} \mathrm{~S}_{2.75} \mathrm{~T}_{4.25}$ & $\mathrm{~V}_{11.25} \mathrm{~S}_{4.25} \mathrm{~T}_{6.25}$ & $\mathrm{~V}_{13.75} \mathrm{~S}_{3.75} \mathrm{~T}_{5.75}$ & $\mathrm{R}_{1} \mathrm{~V}_{12.75} \mathrm{~S}_{6.5} \mathrm{~T}_{6.5}$ \\
\hline 73 & 788 & 827 & $\mathrm{R}_{2} \mathrm{~V}_{18} \mathrm{~S}_{6.5} \mathrm{~T}_{8.5}$ & $\mathrm{R}_{1} \mathrm{~V}_{18} \mathrm{~S}_{6} \mathrm{~T}_{8.25}$ & $\mathrm{R}_{1} \mathrm{~V}_{19} \mathrm{~S}_{6.5} \mathrm{~T}_{9}$ & $\mathrm{R}_{1} \mathrm{~V}_{19} \mathrm{~S}_{7.75} \mathrm{~T}_{9.5}$ & $\mathrm{R}_{2} \mathrm{~V}_{18.75} \mathrm{~S}_{9.5} \mathrm{~T}_{9.5}$ \\
\hline 80 & 915 & 945 & $\mathrm{~V}_{20.75} \mathrm{~S}_{9.25} \mathrm{~T}_{11}$ & $\mathrm{R}_{2} \mathrm{~V}_{21.5} \mathrm{~S}_{11} \mathrm{~T}_{11.25}$ & $\mathrm{R}_{2} \mathrm{~V}_{24.5} \mathrm{~S}_{9.5} \mathrm{~T}_{10.75}$ & $\mathrm{R}_{2} \mathrm{~V}_{23.25} \mathrm{~S}_{13.25} \mathrm{~T}_{11.5}$ & $\mathrm{~V}_{22} \mathrm{~S}_{13.5} \mathrm{~T}_{11.75}$ \\
\hline 84 & 981 & 1010 & $\mathrm{R}_{3 \mathrm{a}}$ & & & & \\
\hline 86 & 1012 & 1040 & & $\mathrm{R}_{3 a}$ & & & \\
\hline 87 & 1029 & 1055 & $\mathrm{~V}_{25.25} \mathrm{~S}_{13.25} \mathrm{~T}_{13.5}$ & $\mathrm{~V}_{25.75} \mathrm{~S}_{15} \mathrm{~T}_{12.75}$ & $\mathrm{R}_{3 \mathrm{a}} \mathrm{R}_{\mathrm{s}} \mathrm{V}_{27.5} \mathrm{~S}_{14.75} \mathrm{~T}_{13.25}$ & $\mathrm{R}_{\mathrm{s}} \mathrm{V}_{26.75} \mathrm{~S}_{16} \mathrm{~T}_{13}$ & $\mathrm{R}_{\mathrm{s}} \mathrm{V}_{26.25} \mathrm{~S}_{15.25} \mathrm{~T}_{14}$ \\
\hline 88 & 1043 & 1073 & & & & $\mathrm{R}_{3 a}$ & \\
\hline 89 & 1060 & 1090 & & & & & $\mathrm{R}_{3 \mathrm{a}}$ \\
\hline 94 & 1138 & 1179 & $\mathrm{~V}_{28.25} \mathrm{~S}_{17.5} \mathrm{~T}_{15}$ & $\mathrm{R}_{\mathrm{s}} \mathrm{V}_{29} \mathrm{~S}_{20} \mathrm{~T}_{13.5}$ & $\mathrm{~V}_{29.75} \mathrm{~S}_{20.75} \mathrm{~T}_{14.75}$ & $\mathrm{~V}_{29.75} \mathrm{~S}_{19} \mathrm{~T}_{14}$ & $\mathrm{~V}_{29} \mathrm{~S}_{17.5} \mathrm{~T}_{15.5}$ \\
\hline 101 & 1262 & 1298 & & & & & \\
\hline 102 & 1282 & 1316 & $\mathrm{R}_{4 \mathrm{a}}$ & & & & \\
\hline 103 & 1304 & 1332 & & $\mathrm{R}_{4 \mathrm{a}}$ & & & \\
\hline 104 & 1324 & 1348 & & & $\mathrm{R}_{4 \mathrm{a}}$ & & \\
\hline 105 & 1340 & 1362 & & & & $\mathrm{R}_{4 \mathrm{a}}$ & \\
\hline 108 & 1387 & 1412 & & & & & $\mathrm{R}_{4 \mathrm{a}}$ \\
\hline 113 & 1468 & 1502 & $\mathrm{R}_{3 \mathrm{~b}}$ & $\mathrm{R}_{3 \mathrm{~b}}$ & & & \\
\hline 114 & 1484 & 1516 & & & $\mathrm{R}_{3 \mathrm{~b}}$ & $\mathrm{R}_{3 \mathrm{~b}}$ & \\
\hline 115 & 1500 & 1530 & & & & & $\mathrm{R}_{3 \mathrm{~b}}$ \\
\hline 119 & 1562 & 1594 & $\mathrm{R}_{4 \mathrm{~b}}$ & $\mathrm{R}_{4 \mathrm{~b}}$ & $\mathrm{R}_{4 \mathrm{~b}}$ & & \\
\hline 12 & 1578 & 1610 & & & & $\mathrm{R}_{4 \mathrm{~b}}$ & $\mathrm{R}_{4 \mathrm{~b}}$ \\
\hline 122 & 1612 & 1643 & & & & & \\
\hline
\end{tabular}

Tab. 4. Combined Analysis of variance of GDDs for flower and seed at two harvest of German chamomile affected by different irrigation regimes and plant densities

\begin{tabular}{|c|c|c|c|c|c|c|c|c|}
\hline \multirow{3}{*}{$\begin{array}{l}\text { Source of } \\
\text { Variation }\end{array}$} & \multirow{3}{*}{ d.f. } & \multicolumn{4}{|c|}{ GDDs } & \multicolumn{3}{|c|}{ Maximum numbers } \\
\hline & & \multicolumn{2}{|c|}{ Flower } & \multicolumn{2}{|c|}{ seed } & \multirow[b]{2}{*}{$\begin{array}{c}\text { Leaf per } \\
\text { plant }\end{array}$} & \multirow[b]{2}{*}{$\begin{array}{l}\text { Sub stem } \\
\text { per plant }\end{array}$} & \multirow[b]{2}{*}{$\begin{array}{c}\text { Tiller per } \\
\text { plant }\end{array}$} \\
\hline & & $\begin{array}{c}\text { First } \\
\text { harvest }\end{array}$ & $\begin{array}{l}\text { Second } \\
\text { harvest }\end{array}$ & $\begin{array}{c}\text { First } \\
\text { harvest }\end{array}$ & Second harvest & & & \\
\hline Year & 1 & $24168.41^{*}$ & $42112.53^{\mathrm{ns}}$ & $42.865 .20^{\prime \prime}$ & $75300.30^{\text {ns }}$ & $1930.25^{\prime \prime}$ & $10.716^{\prime \prime}$ & $8.431^{*}$ \\
\hline E1 $(r / Y)$ & 4 & 0.01 & 362399.43 & 73.20 & 16677.24 & 1.31 & 0.058 & 0.116 \\
\hline Irrigation $(\mathrm{A})$ & 3 & $0.01^{\mathrm{ns}}$ & $15195.34^{* \prime}$ & $0.0001^{\mathrm{ns}}$ & $26650.68^{*}$ & $14.70^{\mathrm{ns}}$ & $0.138^{\mathrm{ns}}$ & $0.059^{\mathrm{ns}}$ \\
\hline$A \times Y$ & 3 & $0.01^{\text {ns }}$ & $46.07^{\mathrm{ns}}$ & $0.0001^{\text {ns }}$ & $879.17^{\text {ns }}$ & $0.21^{\mathrm{ns}}$ & $0.0003^{\mathrm{ns}}$ & $0.001^{\mathrm{ns}}$ \\
\hline Plant Density (B) & 4 & $15262.21^{*}$ & $2122.00^{*}$ & $41386.20^{*}$ & $635.55^{\mathrm{ns}}$ & $23.34^{\circ}$ & $0.373^{\circ}$ & $0.563^{\mathrm{ns}}$ \\
\hline $\mathrm{B} \times \mathrm{Y}$ & 4 & $7.91^{*}$ & $6.53^{\mathrm{ns}}$ & $202.20^{*}$ & $25.57^{\mathrm{ns}}$ & $0.64^{\mathrm{ns}}$ & $0.002^{\mathrm{ns}}$ & $0.006^{\mathrm{ns}}$ \\
\hline$A \times B$ & 12 & $0.01^{\mathrm{ns}}$ & $2.84^{\mathrm{ns}}$ & $0.0003^{\text {ns }}$ & $168.56^{\mathrm{ns}}$ & $11.11^{\mathrm{ns}}$ & $0.375^{*}$ & $0.368^{\mathrm{ns}}$ \\
\hline$A \times B \times Y$ & 12 & $0.01^{\text {ns }}$ & $2.84^{\mathrm{ns}}$ & $0.0003^{\text {ns }}$ & $8.08^{\text {ns }}$ & $0.24^{\mathrm{ns}}$ & $0.002^{\mathrm{ns}}$ & $0.004^{\mathrm{ns}}$ \\
\hline Error & 76 & 0.01 & 516.11 & 15.41 & 769.01 & 8.85 & 0.141 & 0.272 \\
\hline Coefficient of $\mathrm{Var}$ & ance & 0.01 & 1.52 & 0.29 & 1.74 & 10.87 & 9.36 & 14.83 \\
\hline
\end{tabular}

Note: $\mathrm{ns},{ }^{*},{ }^{* *}$ non-significant, significant at $\mathrm{P}<0.05$ and $\mathrm{P}<0.01$, respectively; $\mathrm{df}$, degree of freedom 
48
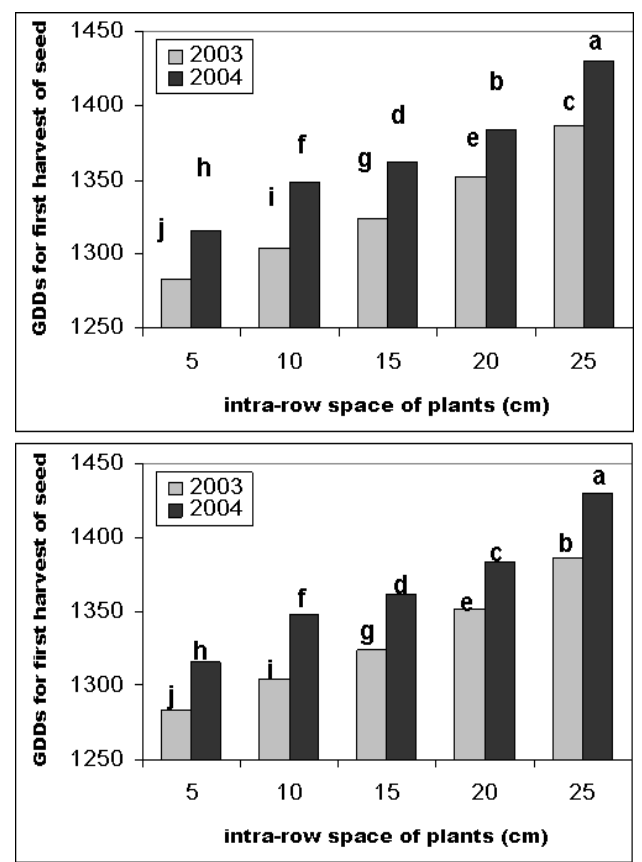

Fig. 2. Means of interaction between year and plant density on GDDs of first harvest of flower and seed. The same letters show non-significant differences

Tab. 5. Means of interaction between irrigation regimes and plant density on the maximum numbers of sub stem per plant

\begin{tabular}{ccccc}
\hline \multirow{2}{*}{$\begin{array}{c}\text { Intra-row } \\
\text { space of } \\
\text { plants }\end{array}$} & \multicolumn{4}{c}{$\begin{array}{c}\text { Irrigation regimes (mm evaporation } \\
\text { from class A pan) }\end{array}$} \\
\cline { 2 - 5 }$(\mathrm{cm})$ & 25 & \multicolumn{4}{c}{50} & 75 & 100 \\
\cline { 2 - 5 } & \multicolumn{3}{c}{ Maximum numbers of sub stem per plant } \\
\hline 5 & $13.833 \mathrm{ab}$ & $16.000 \mathrm{ab}$ & $16.000 \mathrm{ab}$ & $18.333 \mathrm{ab}$ \\
10 & $16.333 \mathrm{ab}$ & $16.000 \mathrm{ab}$ & $16.667 \mathrm{ab}$ & $15.000 \mathrm{ab}$ \\
15 & $19.167 \mathrm{a}$ & $16.000 \mathrm{ab}$ & $18.833 \mathrm{ab}$ & $16.833 \mathrm{ab}$ \\
20 & $14.167 \mathrm{ab}$ & $18.167 \mathrm{ab}$ & $19.500 \mathrm{a}$ & $14.833 \mathrm{ab}$ \\
25 & $17.667 \mathrm{ab}$ & $12.500 \mathrm{~b}$ & $14.500 \mathrm{ab}$ & $15.667 \mathrm{ab}$ \\
\hline
\end{tabular}

Note: The same letters show non-significant differences.

\section{References}

Bertoia, L., R. Burak and A. Nivio (1998). Effect of plant densities on yield and quality of forage maize. Maize Growers Co-operative Newsletter. Santa Catarina, Brazil.

Mann, C. and E. J. Staba (1992). The chemistry, pharmacology and commercial formulations of chamomile, p. 235-280. In: L. E. Craker and J. E. Simon (Eds.), Herbs, Spices and Medicinal plants, Recent Advances in Botany, Horticulture and Pharmacology, Vol. I. Food Product Press, New York.

Michigan State University (1988). User’s Guide to MSTAT-C a software program for the design, management, and analysis of agronomic research experiment, MSU, USA.

Pessarakli, M. (1999). Handbook of plant and crop stress. Marcel and Dekker Inc, New York, pp.1198.

Salamon, I. (1992). Chamomile a medicinal plant. The Herb, Spice and Medicinal Plant Digest. 10(1):1-4.
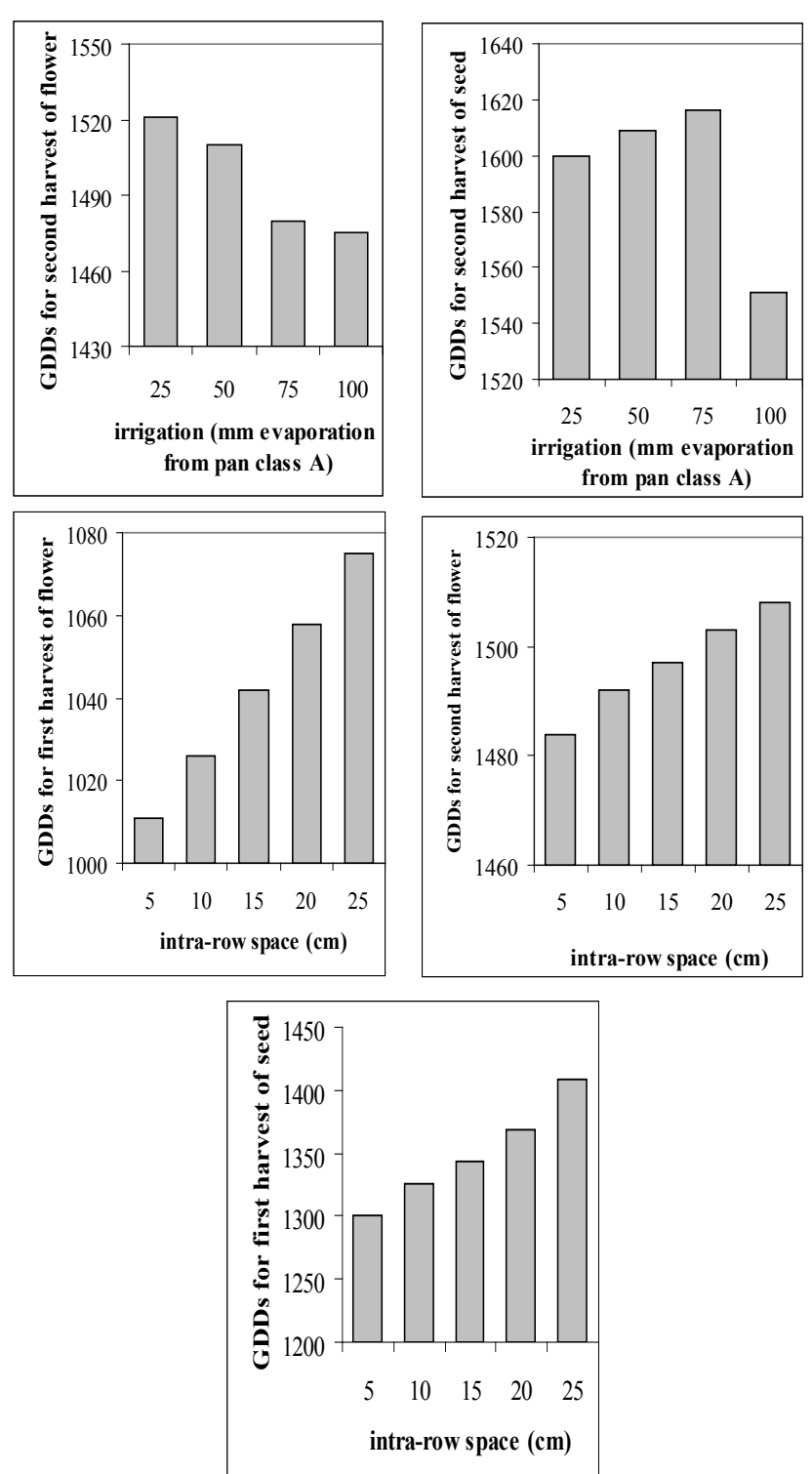

Fig. 3. Means of GDDs for flower and seed harvest under different irrigation regimes and plant densities. The same letters show non-significant differences

Salamon, I. (1998). Genetic resourses of selected medicinal plants in the east Slovak lowland-their evaluation and use. Medicinal Plants Report. 5(5):24-29.

Sani, B. M., K. O. Oluwasemire and H. I. Mohammed (2008). Effect of irrigation and plant density on the growth, yield and water use efficiency of early maize in the Nigerian savanna. ARPN Journal of Agricultural and Biological Science. 3(2): 33-40.

Singh, A. (1982). Cultivation of Matricaria chamomilla. p. 653-657. In: A. Singh, C. K. Atal and B. M. Kapur (Eds.). Cultivation and utilization of aromatic plants. R.R.L. Jammu-Tawi.

Trought, M. C. T. and M. C. Drew (1980). The development of waterlogging damage in wheat seedling (Triticum aestivum L.). II. Accumulation and redistribution of nutrients by the shoot. Plant and Soil. 56:187-199. 